\title{
Multi Sistem Pendidikan Pesantren dan Tantangan Masa Depan
}

\author{
Safradji \\ Dosen STIT Aqidah Usymuni Sumenep \\ achmadshafraji@yahoo.co.id
}

\begin{abstract}
Pesantren or Pondok Pesantren are Islamic boarding school. According to one popular tradition. As social institutions, pesantren have played a major role over the centuries. They emphasise cores values of sincerity, simplicity, individual autonomy, solidarity and self-control. Young men and women are separated from their familier, which contributes to a sense of individual commitment to the faith and close bonding to a teacher. Pesantren aim to deepen knowledge of Qur'an, particularly thruugh the study of Arabic, traditions of exegesis, the Sayings of the Prophet, law and logic. The term pesantren derives from the root word santri or student-pe-santri- or the place of the santri. Pesantren provides to Indonesian citizens at low cost; although today some modern pesantren charge higher fees than previously, they are still significantly cheaper than non-pesantren educational instittutions. The tradisional pattern was for students to work in the

headmaster's rice fields in exchange for food, shelter, and education. All pesantren are led by a group of teachers and religious leaders known Kyai. The Kyai is respected as teacher and devout man. Kyai also play important roles in in the community as a religious leader and in recent years as a political figure. There are Kyai families that have a long history of serving in this role. Some contemporary Kyai are the grandsons and great-grandsons of famous historial figures who established well known pesantren.
\end{abstract}

Kata Kunci: Multi Sistem Pendidikan Pesantren Dan Tantangan Masa Depan

\section{Pendahuluan}

Pondok Pesantren dalam fungsi sosialnya bukan sekedar menjadi lembaga pendidikan, melainkan juga lembaga pergulatan spiritual, lembaga dakwah dan pelestarian budaya, serta pernyataan sejarah pedagogik dalam transmisi pesanpesan substantif Islam. Dengan demikian Pondok Pesantren merupakan pusat perubahan bukan hanya di bidang pendidikan melainkan juga pada kehidupan polotik, budaya, sosial dan keagamaan, setidak-tidaknya untuk lingkungan masyarakatnya. 
Oleh karenanya, Pondok Pesantren seyogyanya memang kita pahami sebaagai satu warisan sekaligus kekayaan penting dari kebudaayaan intelektual kita di Nusantara. Sebab mungkin hanya Pondok Pesantren, suatu kelembagaan tradisional pendidikan tertua di Indonesia yang hingga sekarang masih survive dan bahkan masih banyak diminati masyarakat. Dengan kata lain satu satunya lembaga pendidikan Islam yang mewarisi khazanah intelektual Islam klasik.

Pondok Pesantren dalam perkembangannya memang tampak sengaja mengambil epistemologi pendidikan yang berbeda dengan lembaga pendidikan lainnya. Secara eksklusif tradisi akademik ini dipertahankan dan dikembangkan tanpa harus memetamorfosis ke dalam model dominan: sekolah atau madrasah sebagai model pendidikan modern. Pondok Pesantren menjadi bentuk pendidikan tersendiri dari aneka pendidikan nasional. Dialektika Pondok Pesantren dengan madrasah dan sekolah pun menemukan bentuknya sendiri yang variatif sesuai dengan kadar penerimaannya terhadap infiltrasi negara.

Pondok pesantren menurut akar berdirinya ada dua versi :

1. Berdasar dari Islam sendiri yaitu tarekat. Pondok pesantren mempunyai kaitan yang erat dengan tempat pendidikan khas bagi kaum sufi, dimana berdasarkan fakta bahwa penyiaran Islam di Indonesia pada awalnya lebih banyak dikenal dalam bentuk tarekat dengan dzikiran. Pimpinan tarekat disebut kyai, ia mewajibkan pengikutnya melakukan suluk 40 hari dalam satu tahun, disiapkan tempat penginapan, tempat memasak di kiri kanan masjid.

2. Pengambil-alihan dari sistem pendidikan pesantren yang diadakan oleh orangorang Hindu, dimana pondok pesantren pada masa itu dimaksudkan sebagai tempat mengajarkan ajaran-ajaran agama Hindu, dan fakta lain pondok pesantren bukan berasal dari tradisi Islam, tidak ditemukan lembaga pondok pesantren di negara-negara Islam.

Pondok pesantren di Indonesia diketahui keberadannya setelah abad ke 16, pondok pesantren lembaga pendidikan dan keagamaan Islam tertua di Indonesia. Kaata " pondok" barasal dari bahasa arab " funduk " artinya tempat menginap. Kata "pesantren" barasal dari kata "santri” mendapat affiks "pe - an " menjadi 
pesantren, ada yang mengatakan berasal dari kata "chantrik" yang berarti orang yang sedang belajar kepada guru, yang diajarkan bidang agama dan kitab klasik, terutama bidang akhlak.

Pada dasarnya fungsi utama pesantren adalah sebagai lembaga bertujuan mencetak muslim agar memiliki dan menguasai ilmu-ilmu agama (tafaqquh fi aldin) secara mendalam serta menghayati dan mengamalkannya dengan ikhlas semata-mata ditujukan untuk pengabdiannya kepada Allah swt di dalam hidup dan kehidupannya. Penyelenggaraan kegiatan pendidikan dan pengajaran untuk para santri dengan bebagai macam metode pembelajaran.

\section{Tipologi Pondok Pesantren}

Paling tidak terdapat empat alasan utama pesantren membangun pondok (asrama) untuk para santrinya.

Pertama, ketertarikan santri santri untuk belajar kepada seorang kyai dikarenakan kemasyhuran atau kedalaman serta keluasan ilmunya yang mengharuskannya untuk meninggalkan kampung halamannya untuk menetap di kediaman kyai itu.

Kedua, kebanyakan pesantren adalah tumbuh dan berkembang di daerah yang jauh dari keramaian pemukiman penduduk sehingga tidak terdapat perumahan yang cukup memadai untuk menampung para santri dengan jumlah banyak.

Ketiga, terdapat sikap timbal balik antara kyai dengan santri yang berupa terciptanya hubungan kekerabatan seperti halnya hubungan ayah dan anak. Sikap timbal balik ini menimbulkan keakraban dan kebutuhan untuk saling berdekatan secara terus menerus dalam jangka yang lama.

Keempat, untuk memudahkan dalam pengawasan dan pembinaan kepada para santri secara intensif dan istiqamah. Hal ini dapat dimungkinkan jika tempat tinggal antara guru dan murid berada dalam satu lingkungan yang sama. 
Seiring dengan laju perkembangan masyarakat maka pendidikan pesantren baik tempat bentuk hingga substansi telah jauh mengalami perubahan. Pesantren tidak lagi sesederhana seperti apa yang digambarkan seseorang, akan tetapi pesantren dapat mengalami perubahan sesuai dengan pertumbuhan dan perkembangan zaman. Ada empat tipologi pondok pesantren :

1. Pesantren Salafi yaitu pesantren yang tetap mempertahankan pelajaran dengan kitab-kitab klasik dan tanpa diberikan pengetahuan umum. Model pengajarannyapaun sebabagaimana yang lazim diterapkan dalam pesantren salaf yaitu dengan metode sorogan dan wetonan.

2. Pesantren khalafi yaitu pesantren yang menerapkan sistem pelajaran klasikal (madrasi ) memberikan ilmu umum dan ilmu agama serta juga memberikan pendidikan keterampilan.

3. Pesantren kilat yaitu pesantren yang berbentuk semacam training dalam waktu relatif singkat dan biasa dilaksanakan pada waktu libur sekolah. Sedangkan santri terdiri dari siswa sekolah yang dipandang perlu mengikuti kegiatan keagamaan di pesantren kilat. Sedangkan materinya menitik beratkan pada keterampilan ibadah dan kepemimpinan.

4. Pesantren terintegrasi yaitu pesantren yang lebih menekankan pada pendidikan vocasional atau kejuruan sebagaimana balai latihan kerja di Departemen Tenaga Kerja dengan program yang terintegrasi. Sedangkan santri mayoritas barasal dari kalangan anak putus sekolah atau para pencari kerja. ${ }^{1}$

Sedangkan menurut Mas'ud dkk ada beberapa tipologi atau model pondok pesntren :

1. Pesantren yang mempertahankan kemurnian identitas asli sebagai tempat mendalami ilmu ilmu agama ( tafaqquh fil-din ) bagi para santrinya. Semua materi yang diajarkan di pesantren ini sepenuhnya bersifat keagamaan yang bersumber dari kitab-kitab berbahasa Arab ( kitab kuning ) yang ditulis oleh para ulama' abad pertengahan. Pesantren model ini masih banyak kita jumpai

\footnotetext{
${ }^{1}$ Departemen RI, Pola Pembelajaran Di Pesantren
} 
hingga sekarang seperti pesantren Lirboyo di Kediri Jawa Timur dan beberapa pesantren di daerah Sarang Kabupaten Rembang Jawa Tengah dan lain lain.

2. Pesantren yang memasukkan materi materi umum dalam pengajaran namun dengan kurikulum yang disusun sendiri menurut kebutuhan dan tidak mengikuti kurikulum yang ditetapkan pemerintah secara nasional sehingga ijazah yang dikeluarkan tidak mendapatkan pengakuan dari pemerintah sebagai ijazah formal.

3. Pesantren yang menyelenggarakan pendidikan umum di dalam baik berbentuk madrasah (sekolah umum berciri khas Islam di dalam naungan kemenag) maupun sekolah ( sekolah umum di bawah Kemendikbud ) dalam berbagai jenjang bahkan ada yang sampai Perguruan Tinggi yang tak hanya meliputi fakultas-fakultas keagamaan melainkan juga fakultas-fakultas umum, seperti pesantreen Tebu Ireng di Jombang Jawa Timur.

4. Pesantren yang merupakan asrama pelajar Islam dimana para santri belajar di sekolah-sekolah atau perguruan tinggi di luarnya. Pendidikan agama di pesantren ini diberikan diluar jam-jam sekolah sehingga bisa diikuti oleh semua santrinya. ( 2002:149-150)

Salah satu keunikan pesantren adalah independensinya yang kuat. Sama halnya madrasah, pesantren tumbuh dan berkembang dari masyrakat. Kuatnya independensi ini menyebabkan pesantren memiliki keleluasaan dan kebebasan relatif yang tidak harus memihak atau mengikuti model baku yang ditetapkan pemerintah dalam bidang pendidikan. Pesantren bebas mengembangkan model pendidikannya tanpa harus mengikuti standarisasi dan kurikulum yang ketat. Hal ini ditambah dengan kecendrungan sentralistik yang berpusat di tangan kyai. Akibatnya, model pendidikan yang berjalan di pesantren menjadi sangat beragam sesuai dengan kecendrungan dan misi yang ingin dikembangkan oleh sang kyai, pemilik pesantren tersebaut.

Untuk memudahkan klasifikasi, ada beragam tipologi yang bisa diajukan untuk melihat pendidikan di pesantren. Pertama, pesantren tradisional (salaf) dan pesantren modern (khalaf). Disebut tradisional (salaf) karena sistem 
pengajarannya masih menggunakan sistem sorogan, wetonan dan bandongan, tampa kelas dan batas umur. Sedangkan disebut modern (khalaf) karena sistem pengaajarannya sudah menggunakan sistem kelas, kurikulum dan batas umur.

Tipologi kedua, adalah pesantren dengan pendidikan formal yaitu jalur sekolah, jalur luar sekolah dan jalur pra-sekolah. Jalur luar sekolah dan jalur prasekolah. Jalur sekolah menggunakan kurikulum Departemen Agama dan Depdikbub seperti MI/SD, MTs/SLTP, MTs Terbuka/SLTP Terbuka, MA/SMU, PTA/PTU. Jalur luar sekolah yaitu madrasah diniyah (MDA,MDW,MDU) Paket A, Paket B dan Paket C. Jalur pra sekolah yaitu RA/TK

Ketiga, pondok pesantren dibedakan berdasarkan jumlah santrinya. Disebut pesantren besar kalau jumlah santrinya di atas 5000. Jika jumlah santri mencapai antara 3000-5000 disebut menengah. Jika jumlah saantrinya antara 1000-3000 disebut sedang. Jika santrinya kurang 1000 biasanya disebut pesantren kecil.

Keempat, pondok pesantren berafiliasi dan tidak berafiliasi dengan organisasi massa Islam tertentu, seperti Rabithah Ma'ahid al-Islami (RMI), Muhammadiyah, Persis, al-Wasliyah dan lain-lain.

Kelima, pondok pesantren yang menampung santri mukim dan santri kalong. Santri mukim yaitu santri yang belajar dan bertempat tinggal di asrama lingkungan pondok. Sedangkan santri kalong adalah santri yang bertempat tinggal di asrama pondok tapi belajar di madrasah atau sekolah umum di luar pesantren.

Keenam, pondok pesantren pedesaan dan perkotaan. Hal ini bisa didasarkan pada letak sebuah pesantren dan asal santri. Pesantren pedesaan kebanyakan berada di desa bahkan jauh dari pusat keramaian dan santrinya umumnya berasal dari desa. Sedangkan pesantren perkotaan dikenal dengan pesantren urban atau sub urban. ${ }^{2}$

${ }^{2}$ Husni Rahim, Arah Baru Pendidikan Islam di Indonesia 


\section{Metode Pendidikan Di Pesantren}

Sebagai lembaga pendidikan Islam yang telah bergumul lama dengan realitas zaman, pesantren telah mengalami pergeseran dan perubahan baik terkait dengan institusi maupun kurikulum. Kategori pesantren tradisional dan modern ternyata diindikasikan dengan pola perubahan metode yang dipakainya. Maka, dari perubahan tersebut akan terklasifikasi antara metode tradisional dan metode modern. Departemen Agama Republik Indonesia(sekarang Kementrian Agama Republik Indonesia ) melaporkan bahwa metode penyajian atau penyampaian materi di pesantren ada yang bersifat tradisional ada yang bersifat modern. Penyampaian materi yang bersifat tradisional adalah halaqah, wetonan, dan sorogan. Sedangkan, metode modern merupakan metode yang masih diintrodusir berdasarkan pendekatan ilmiah.

a. Metode-Metode Tradisional

1. Metode sorogan (Individual Learning Proses )

Merupakan suatu metode yang ditempuh dengan cara guru menyampaikan pelajaran kepada santri secara individual. Sasaran metode ini adalah kelompok santri pada tingkat rendah, yaitu yang baru menguasai Al-Qur'an atau yang baru belajar Al-Qur'an. Di samping itu penerapan metode ini kurang efektif dan efisien karena menghabiskan waktu yang cukup lama.

Habib Chirzin mengemukakan pendapatnya seperti yang dikutip oleh M. Dawam Raharjo bahwa metode sorogan adalah suatu metode di mana santri mengajukan sebuah kitab kepada kyai untuk dibaca di hadapan kyai. Kalau di dalam membaca dan memahami terdapat kesalahan, kesalahan tersebut langsung dibenarkan oleh kyai. ${ }^{3}$ Ini artinya santri dituntut kemandiriannya dalam belajar yang berhasil atau tidaknya sangat bergantung pada diri sendiri.

\section{Metode Wetonan}

Selain metode pengajaran dalam bentuk sorogan di pondok pesantren juga terdapat metode wetonan dalam pengajarannya. Metode wetonan adalah kyai

\footnotetext{
${ }^{3}$ M. Dawam Raharjo, Pergulatan Dunia Pesantren Membangun Dari Bawah, (Jakarta:LP3ES. 1995)
} 
membaca suatu kitab dalam waktu tertentu dan santri membaca kitab yang sama, kemudian santri mendengarkan dan menyimak bacaan tersebut. Metode ini merupakan metode utama di lingkungan pesantren.

\section{Metode Bandongan (Collective Learning Process)}

Sidi Gazalba mengatakan bahwa metode bandongan adalah sistem pengajaran di mana kyai membaca kitab, sementara murid memberi tanda dari struktur kata atau kalimat yang dibaca oleh kyai. ${ }^{4}$ Dalam prakteknya, metode ini lebih menekankan ketaatan kepada kyai. Metode ini lebih menekankan aspek perubahan sikap (moral) setelah santri memahami isi kitab yang dibaca oleh kyai.

4. Halaqah

Halaqah dalam arti bahasanya adalah lingkaran santri. Sedangkan yang dimaksud dengan halaqah di sini adalah sekelompok santri yang belajar di bawah bimbingan seorang guru atau ustaz atau kyai yang belajar bersama dalam satu tempat untuk mendiskusikan pemahaman terhadap suatu masalah atau suatu kitab tertentu.

Dalam mempelajari kitab-kitab agama Islam, selain metode pembelajaran yang telah disebutkan di atas, juaga terdapat metode pembelajaran halaqah di mana santri bersama-sama dengan kyai atau ustadz berada dalam satu tempat tertentu mempelajari dan mendiskusikan suatu kitab tertentu pula secara bersama-sama.

5. Mudzakarah/Musyawarah

Yang dimaksud mudzakarah menurut Ismail dan Abdul Mukti adalah melakukan pertemuan ilmiah secara khusus membahas persoalan agama pada umumnya. Dengan penerapan metode ini berfungsi agar santri terlatih untuk memecahkan suatu persoalan dengan menggunakan suatu rujukan kitab-kitab yang tersedia. ${ }^{5}$ Bahkan dalam metode ini santri secara akselerasi akan membangun meintal yang kuat dalam mengemukakan pendapat secara demokratis dan melatih santri untuk menghargai pendapat dari orang lain.

\footnotetext{
${ }^{44}$ Sidu Galba, Pesantren sebagai wadah komunikasi, (Jaakarta, PT Rineka Cipta, 1995)

${ }^{5}$ Ismail \& Abdul Mukti, Pendidikan Islam, Demokrasi dan Masyarakat Madani, ( Yogyakarta Pustaka Pelajar)
} 


\section{Sistem Pendekatan dalam Pembelajaran di Pesantren}

\section{Pengertian}

Sistem dapat diartikan sebagai suatu perangkat atau mekanisme yang terdiri dari bagian - bagian di mana, satu sama lain saling berhubungan dan saling keterkaitan. Dengan demikian pengertian sistem pendekatan dalam pempelajaran di pesantren adalah cara-cara pendekatan yang ditempuh dalam kegiatan pembelajaran kitab-kitab kuning di suatu pesantren agar tujuan yang ditetapkan dapat dicapai secara optimal.

Pendekatan dalam pembelajaran itu diciptakan untuk memudahkan segala usaha dalam pencapaian tujuan. Oleh karena itu penciptaan beberapa pendekatan biasanya disesuaikan dengan kemungkinan dapat tidaknya dipergunakan untuk mencapai pendidikan yang dicita-citakan itu. ${ }^{6}$

\section{Prinsip-prinsip Umum dalam pembelajaran}

Bertitik tolak dari sistem pendekatan di atas, maka dalam kegiatan pembelajaran di suatu pesantren prinsip-prinsip umum belajar dan motifasi yang perlu diterapkan pada umumnya meliputi:

1. Prisip Kebermaknaan

Prinsip ini memiliki arti bahwa para santri akan mempelajari sesuatu hal apapun adalah jika sesuatu itu bermamfaat atau bermakna bagi kehidupannya baik untuk masa kini maupun masa depan, baik bagi kepentingan hidupnya sendiri maupun untuk kepentingan masyrakatnya. Dengan kata lain salah satu faktor yang mendorong atau memotivasi santri untuk belajar adalah adanya mamfaat praktis dari sesuatu yang dipelajarinya itu dalam kehidupan. Oleh karena itu biasanya seorang kyai dalam mengajarkan suatu materi pelajaran kepada para santrinya:

a) Menghubungkan pelajaran yang ia berikan dengan minat dan nilai-nilai santri

b) Menghubungkan pelajaran dengan kehidupan masa depan para santri.

2. Prinsip prasyarat

${ }^{6}$ Departemen Agama RI, Pola Pembelajaran Di Pesantren, Tahun 2001 
Pada prinsip ini seorang santri akan tergerak untuk mempelajari sesuatu hal yang baru apabila ia memiliki semua prasyarat yang diperlukan untuk mempelajarinya. Bila santri memilikinya, maka ia akan merasa bahwa pelajarannya itu akan bermakna. Ia akan mampu menerima hubungan pengetahuan yang lebih dan lainnya. Hal ini dapat dimengerti karena kyai di pesantren tidak hanya berfungsi sebagai pengajar tetapi juga sebagai orang tua bagi para santri yang senantiasa memberikan bimbingan-bimbingannya. Sehingga dalam struktur sosialnya, pesantren lebih mencerminkan sebagai kesatuan keluarga dalam jumlah besar di mana santri yang masih muda usianya( junior ) memperlakukan dan menganggap sebagai kakaknya terhadap santri yang lebih tua (senior), demikian pula sebaliknya.

\section{Prinsip Keterbukaan}

Prinsip ini menuntut agar pendidik mendorong para santrinya agar lebih banyak lagi mempelajari sesuatu dengan cara penyajian yang disusun sedemikian rupa sehingga pesan-pesan pendidik terbuka bagi santri. Untuk itu para pendidik biasanya melakukan langkah-langkah berikut ini :

a) Menjelaskan kepada para santri tentang tujuan-tujuan pembelajaran yang jelas sehingga segala sesuatu yang diharapkan oleh kyai dapat dimengerti oleh para santrinya.

b) Menunjukkan hubungan-hubungan sebab akibat, mengapa hal-hal tersebut baru dipelajari.

c) Menghindari segala penjelasan yang dapat mengurangi minat belajar para santri.

d) Merangsang kemampuan sensoris para santri dengan bantuan alat-alat peraga yang relevan dengan materi pelajaran.

e) Memberikan kesempatan kepada para santri untuk menanyakan hal-hal yang belum dimengerti atau belum jelas

\section{Prinsip Kebaruan}

Para santri biasanya akan lebih tertarik unutuk mempelajari sesuatu hal apabila hal itu adalah sesuatu yang baru yang belum diketahuinya. 


\section{Prinsip Keterlibatan}

Prinsip ini menjelaskan bahwa para santri dapat belajar lebih giat dan aktif dalam berbagai kegiatan pembelajaran di pesantren. Keterlibatan para santri secara aktif ini biasanya dilakukan pada waktu kegiatan praktek ibadah.

6. Prinsip Kebersamaan

Dalam dunia pesantren dikarenakan kehidupan para santri senantiasa berada dalam kehidupan sosial yang intens, maka dalam kegiatan belajarpun mereka akan melakukannya bersam-sama. Misalnya sewaktu ditugaskan untuk menghafalkan teks-teks tertentu mereka akan melakukannya secara bersama-sama di dalam bilik masing-masing. ${ }^{7}$

\section{Komunikasi Interaktif Kyai dan Santri}

Salah satu kelebihan sistem pendidikan pesantren dibandingkan sistem pendidikan lain adalah adanya hubungan yang akrab dan bersifat khusus humanis antara kyai atau ustadz dengan orang tua atau keluarga santri itu sendiri. Seorang calon santri datang ke pesantren umumnya diantarkan oleh kedua orang tua atau keluarganya, kemudian dititipkan atau dipasrahkan secara langsung kepada kyai atau ustadz untuk didik di pesantren. Hubungan semacam itu tidak hanya ketika penyerahan, melainkan dalam banyak peristiwa pendidikan di pesantren. Sementara santri itu pun hidup bersama kyai atau ustadz setiap hari dalam kehidupan bapak-anak dalam pesantren.

Hubungan akrab ini menciptakan suasana pembelajaran yang sangat intens dan familier. Pembelajaran yang terjadi tidak hanya terbatas pada transformasi ilmu, melainkan juga pada seluruh perilaku kehidupan.

Dalam kasus pesantren yang cukup besar, peran-peran kyai ini biasanya dikejawantahkan oleh para ustadz atau santri senior yang dimanifestasikan dalam tata tertib pergaulan dalam pesantren.

${ }^{7}$ Ibid 
Dari hubungan yang positif itu dapat menimbulkan hal-hal positif di bawah ini, yang kemudian menjadi watak dan ciri santri:

1. Tumbuhnya sikap rendah hati ( tawaddu' ) terhadap yang lebih bawah dan sikap hormat ( ta'dzim ) kepada yang lebih atas, terutama dalam hal ilmu dan ibadah.

2. Terbentuknya kepribadian yang berpola hidup hemat dan sederhana.

3. Terbiasa untuk hidup secara mandiri, terbiasa untuk mengerjakan hal-hal yang hina tapi mulia seperti mencuci, membersihkan kamar tidur serta memasak sendiri.

4. Tumbuhnya jiwa suka menolong kepada orang lain. Hal ini disebabkan karena suasana pergaulan di pesantren yang lebih familiar dan menjunjung kesetaraan.

5. Terbentuknya sikap disiplin.

6. Timbulnya kesanggupan untuk hidup prihatin, dalam rangka mencapai tujuan mulia.

\section{Pendekatan Dalam Pembelajaran}

Pendekatan yang dipergunakan dalam pembelajaran di pesantren biasanya meliputi hal-hal berikut ini:

1. Pendekaatan Psikologis

Pendekatan ini tendensi utamanya adalah dilakukannya dorongan atau motivasi dari kyai kepada para santrinya dengan dorongan yang bersifat pesuasif, yaitu suatu dorongan yang mampu menggerakkan daya kognitif, afektif serta psikomotorik. Seorang kyai sewaktu mengajar para santrinya tidak hanya menekankan pada transfer ilmu secara lisan, tetapi ia melakukannya dengan menggunakan bahasa jiwa (batin) sehingga keterlibatan santri tidak hanya akal (pikiran) nya tetapi juga hati atau batinnya ikut terlibat.

2. Pendekatan Sosio Kultural

Pendekatan ini menghendaki pada usaha pengembangan sikap-sikap pribadi dan sosial sesuai dengan kehidupan yang terjadi di masyrakat. Hal ini menuntut pada adanya inovasi atau pembaharuan-pembaharuan sesuai dengan tuntutan 
keadaan. Pesantren dalam merespon tuntutan ini melakukannya melalui kegiatan pembelajaran dengan menggunakan metode musyawarah atau bahstsui masaail.

3. Pendekatan Keimanan

Yaitu suatu pendekatan yang dalam pelaksanaan pembelajaran berusaha menjelaskan bahwa semua ilmu yang diajarkan akan membawa konsekuensi keyakinan/keimanan para santri kepada mentauhidkan Allah.

4. Pendekatan Sejarah

Pendekatan ini memberikan arah penekanan dalam kegiatan pembelajaran untuk digunakannya pengalaman, kejadian, peristiwa( sejarah ) ummat, tokoh dan nabi terdahulu sebagai satu sisi yang dapat digunakan untuk pemberian pelajaran kepada para santri. Dalam pelaksanaannya pendekatan ini menghendaki ditampilkannya kisah-kisah atau cerita tentang masa lalu yang memiliki nilai-nilai pendidikan agar menjadi pelajaran bagi para santri untuk kehidupannya.

5. Pendekatan Filosofis

Yaitu suatu pendekatan dalam kegiatan pengajaran kepada para santri untuk difungsikannya penalaran mereka dalam menelaah materi pelajaran yang disampaikan sehingga kebenaran yang diterima tidak hanya berdasarkan keimanan tetapi juga berdasarkan kebenaran dari pemikiran. Pendekatan ini walaupun lebih sering digunakan untuk menyampaikan pengajaran tauhid/aqidah, namun dapat juga digunakan untuk menyampaikan mata pelajaran lain seperti fiqh, tafsir serta lainnya. ${ }^{8}$

\section{Tantangan Masa Depan Pendidikan Pesantren}

Menghadapi era globalisasi dan informasi pondok pesantren perlu meningkatakan perannya karena agama Islam yang dibawa oleh Nabi Muhammad saw. Sebagai agama yng terakhir dan berlaku untuk seluruh dunia sepanjang 
masa. Ini berarti ajaran Islam adalah global dan melakukan globalisasi untuk semuanya (surat al-Hujurat,13). Kunci dari ayat di atas yakni setiap persaingan yang keluar sebagai pemenang adalah yang berkualitas yaitu memiliki imantakwa, kemampuan, ilmu pengethuan, tehnologi dan keterampilan. ${ }^{9}$

Tuntutan globalisasi tidak mungkin bisa dihindari, maka salah satu langkah bijak kalau tidak mau dikatakan kalah dalam persaingan, adalah mempersiapkan pesantren agar tidak ketinggalan kereta. Pada tataran ini, masih banyak pembenahan dan perbaikan yang harus dilakukan pesantren. Paling tidak ada tiga yang harus dilakukan pesantren sesuai dengan jati dirinya.

Pertama, pesantren sebagai lembaga pengkaderan ulama, maka fungsi ini tetap harus melekat pada pesantren karena pesantrenlah satu-satunya lembaga pendidikan Islam yang siap mendidik dan mempersiapkan ulama dan ulama yang dilahirkan oleh pesantren tidak hanya pandai ilmu agama, karena tuntutan modernisasi dan globalisasi mengharuskan ulama memikili kemampuan lebih, kapasitas intelektual memadai, wawasan akses pengetahuan dan informasi yang cukup serta responsif terhadap perkembangan dan perubahan yang terjadi.

Kedua, pesantren sebagai lembaga pengembangan ilmu pengetahuan khususnya agma Islam. Pada tataran ini pesantren masih lemah di tingkat pengembangan ilmu dan tehnologi. Kebanyakan pesantren hanya pengajarkan ilmu agma dalam arti transfer of knowledge tanpa upaya lebih lanjut pengembangan ilmu. Hal ini bisa dimengerti karena sistem pembelajaran di pesantren masih berkutat pada metode hafalan dan kecendrungan pengayaan materi ilmu-ilmu agama an sich. Selain itu, tiadanya kurikulum pendidikan agama Islam yang baku dan bisa dipedomani untuk mengajarkan suatu ilmu. Ketiadaan kurikulum ini menyebabkan proses belajar mengajar terjadi asal-asalan dan terserah pengasuh pesantren, tanpa program yang jelas, materi apa yang diajarkan dan kapan suatu pelajaran selesai diajarkan. Untungnya sekarang banyak pesantren yang membuka madrasah atau sekolah yang integral dengan pesantren. Sehingga kurikulum pendidikan agama Islam yang ditrapkan pemerintah (Depag

${ }^{9}$ Husni Rahim, Arah Baru Pendidikan Islam Di Indonesia 
dan Dikbud) daapat diajarkan di pesantren. Dari sekolah dan madrasah inilah diharapkan lahir integrasi ilmu-ilmu agama dan ilmu umum. Pesantren jelas memilki potensi sebagai "lahan" pengembangan ilmu agama. Maka jika ilmu agama ini diintegrasikan dengan ilmu-ilmu sosial kontemporer maka akan lahir kadar-kader ulama yang tangguh di dua bidang ini

Ketiga, pesantren harus mampu menempatkan dirinya sebagai transformator, motifator dan inovator. Kehadiran pesantren dewasa ini telah memerankan funsi-fungsi itu meskipun dalam taraf yang perlu dikembangkan lebih lanjut. Sekolah salah satu komponen masyarakat, pesantren memiliki kekuatan dan "daya tawar" untuk melakukan perubahan-perubahan yang berarti. Persoalannya, maukah pesantren melakukannya . $^{10}$

Dalam khazanah tradisi pesantren, terdapat kaidah hukum yang menarik untuk diresapi dan diaplikasikan oleh lembaga unik ini sebagai lembaga pendidikan yang mesti merespon tantangan dan "kebaruan" zaman. Kaidah itu berbunyi, “al-muhafadzatu 'ala al-qadim al-shalih wa al-akhzu bi al-jadid alashlah" yang artinya melestarikan nilai-nilai Islam lama yang baik dan mengambil nilai-nilai baru yang lebih baik. Kaidah ini mengindikasikan bahwa pesantren patut memelihara nilai-nilai tradisi yang baik sembari mencari nilainilai baru yang sesuai dengan konteks zaman agar tercapai akurasi metodologis dalam mencerahkan peradaban bangsa. Hal ini juga berarti bahwa lembaga pendidikan Islam tidak bisa lepas dari hukum dialektika peradaban antara landasan pendidikan Islam yaitu Al-Qur'an dan hadis dengan relitas zaman.

Jika tradisi besar Islam direproduksi dan diolah kembali, ummat Islam memperoleh keuntungan yang besar, yaitu memiliki tradisi baru yang lebih baik dengan menyesuaikan dengan alur perkembangan zaman. Maka, ketika pesantren tampil dengan wajah baru akan menciptakan apa yang disebut Nurcholish Majid dengan daya gugah baru (psychological striking force). Untuk itu, tidak arif rasanya jika para pengelola pondok pesantren mengabaikan arus mordernisasi sebagai penghasil nilai-nilai baru yang baik meskipun ada sebagian yang buruk

\footnotetext{
${ }^{10}$ Ibid
} 
apabila pesantren ingin progresif mengimbangi perubahan zaman. Dengan tidak meninggalkan ciri khs keislaman, pesantren mesti merespons perkembangan zaman dengan cara-cara kreatif, inovatif dan transformatif. Alhasil, persoalan tantangan zaman modern yang secara realitas akan menciptakan segala produk amoral yang menyebabkan tirai-tirai batas ruang dan waktu seperti dalam gejala global media informasi dapat dijawab secara akurat, tuntas dan tepat sasaran oleh lembaga pendidikan Islam seperti pesantren atau lembaga lainnya. ${ }^{11}$

Dalam sebuah lembaga seperti apapun, bentuk lembaga tersebut baik dalam lingkup makro, maupun mikro, pasti memiliki sistem untuk mengatur jalannya kelembagaanya. Pesantren sebagai institusi yang merepresentasikan pendidikan Islam memiliki sistem yang sangat khas. Bahkan, bisa dikatakan berbeda dengan lembaga-lembaga lainnya yang bergerak dalam bidang yang sama (pendidikan Islam ). Secara historis, pergulatan sistem pendidikan pesantren sudah dimulai sejak kolonialisme mencengkram di Indonesia. Ditambah lagi dengan gerakangerakan baru yang berbaju modernisasi sehingga pendidikan pesantren harus mampu beradaptasi dengan tuntutan-tuntutan yang berkembang.

Secara eksternal, masa depan pendidikan Islam dipengaruhi oleh tiga unsur besar: globalisasi, demokratisasi dan liberalisasi Islam. Globalisasi tidak sematamata menpengaruhi sistem pasar, tetapi juga sistem pendidikan. Penetrasi budaya global terhadap kehidupan masyarakat Indonesia akan direspons secara berbedabeda oleh kalangan pendidikan: permisif, defensif dan transformatif. Kelompok pertama, akan cendrung menerima begitu saja pola dan model budaya global yang dilahirkan melalui tehnolohi informasi tanpa memahami nilai dan substansinya. Sebaliknya, kelompok kedua akan apriori terhadap capaian budaya dan peradaban global, semata-mata karena tidak datang dari tradisi yang diikutinya selama ini. Sedangkan kelompok ketiga, berusaha mendialogkan antara budaya global dengan budaya lokal sehingga terjadi sintesis budaya yang dinamis dan harmonis.

Demokratisasi merupakan isu lain yang mempengaruhi masa depan pendidikan Islam Indonesia. Tuntutan demokratisasi pada awalnya ditujukan pada

${ }^{11}$ Azyumardi Azra, Modernisasi Pendidikan Islam 
sistem politik negara sebagai 'perlawanan' terhadap sistem politik yang otoriter. Dalam perkembangannya, tuntutan ini mengarah pada sistem pengelolaan berbagai bidang kehidupan termasuk pendidikan. Jika sebelumnya sistem pendidikan bersifat sentralistik, seragam dan dependen, maka belakangan berkembang tuntutan pengelolaan pendidikan yang lebih otonom dan beragam. Di samping itu, tuntutan partisipasi masyarakat khususnya dalam pengawasan mutu pendidikan semakin meningkat, yang menuntut pengelolaan pendidikan yang transparan dan bertanggung jawab. Termasuk ke dalam tuntutan demokratisasi ini adalah menggeser paradigma pendidikan sehingga menekankan pada peran siswa secara aktif.

Di samping kedua isu di atas, hal lain yang sangat penting bagi perkembangan masa depan pendidikan Islam adalah masalah liberalisasi Islam. Agama ini telah berkembang dan dipeluk oleh berbagai komunitas yang sangat beragam dan kompleks. Hal ini meniscayakan adanya proses dialektika antara ajaran Islam dengan kondisi lokal sehingga menghasilkan pemahaman agama yang fungsional yang dapat berlaku dalam lingkungan pemeluknya. Sementara itu, perkembangan dalam berbagai kehidupan mutakhir sebagian tidak mendapatkan penjelasan yang cukup tegas dari teks-teks suci. Padahal, jawaban agama atas masalah-masalah yang baru muncul itu tidak boleh absen. Dalam hal ini muncul tuntutan lieberalisasi Islam, baik dalam perspektif yang ekstrim maupun perspektif moderat. Dalam pengertian ekstrim, liberalisasi Islam berarti mengabaikan sama sekali teks-teks suci ketika membahas isu-isu yang memang tidak dijelaskan secara eksplisit di dalamnya. Sedangkan perspektif yang moderat menyadari perlunya penafsiran yang bebas terhadap teks-teks suci sejauh konsisten dengan nilai dasar yang dikandungnya, sehingga isu pendidikan apapun yang bekembang dewasa ini pada dasarnya memiliki relevansi dengan essensi ajaran agama. ${ }^{12}$

Upaya peningkatan mutu madrasah/ pesantren merupakan tuntutan yang makin mendesak dan tidak dapat dihindari dan kepampuan bersaing hanya

\footnotetext{
${ }^{12}$ Husni Rahim, Arah Baru Pendidikan Islam di Indonesia
} 
mungkin muncul bila kita “ berkualitas “. Oleh karena itu, untuk memberi gambaran madrasah pada masa depan, perlu dirumuskan gambaran tentang visi madrasah dalam alam globalisasi. Visi madrasah tersebaut adalah menjadi madrasah sebagai “ sekolah plus " yang bekualitas, berkarakter dan mandiri. Madrasah plus adalah madrasah yang menyiapkan anak didik mampu dalam sains dan teknologi, namun tetap dengan identitas keislamannya. Ini sesuai dengan konsep madrasah adalah sekolah umum yang berciri khas Islam. Dalam upaya peningkatan kualitas tersebut dunia pendidikan Islam masih berkutat dengan "kualitas guru" yang belum memadai.

Untuk menjadi pesantren sebagai lembaga pendidikan ideal, tentu saja harus menghadapi dan menuntaskan beragam persoalan yang saat ini sedang menantang atau bahkan mengancamnya. Disadari atau tidak, gempuran modernisasi, dengan segala dampaknya, membuat pesantren agak kelimpungan dalam menghadapi ragam masalah yang dihadapi. Pada sisi lain, pesantren belum bisa melakukan integrasi antardisiplin keilmuan secara utuh dan interdependensi, misalnya antara ilmu "agama" dan ilmu "umum" (meskipun di beberapa pesantren sama-sama diajarkan) dibiarkan berjalan sendiri-sendiri sehingga tidak menghasilkan pemahaman yang benar-benar "baru" mecerahkan umat dan sekaligus tetap genuine. Manajemen pesantren juga masih menunjukkan wajah serupa, pesantren meski tidak semuanya, selama ini dikelola seadanya dengan kesan menonjol pada penanganan individual dan bernuansa kharismatik. Orientaasi kedepan menjadi kurang jelas dan terbebani persoalan-persoalan praktis keseharian, visi yang belum jelas terumuskan secara konkret menjadi terserap dalam kebijakan pesantren yang bersifat sesaat.

Persoalan-persoalan yang disebutkan di atas merupakan agenda pertama yang harus diselesaikan pesantren. Persoalan tersebut mesti dicarikan solusinya melalui kekayaan yang dimiliki pesantren itu sendiri yaitu tradisi (turats/al-qadim al-shalih). Warisan tersebut hendaknya dibaca kembali untuk menemukan nilainilai substansi yang menjadi inti dari keseluruhan tradisi tersebut serta 
direkonstruksi untuk dikembangkan berdasarkan perubahan kehidupan konkret yang mengitarinya. ${ }^{13}$

\section{Strategi Pendidikan Pesantren}

Kata strategi berasal dari bahasa Inggris "strategy" yang maksudnya "the art of planning operations in war, especially of the movements of armies and navies into favourable positions for fighting" yang artinya seni dalam operasi yang direncanakan khususnya gerakan-gerakan pasukan darat dan laut untuk menempati posisi-posisi yang menguntungkan alam pertempuran. Disampaing itu "strategi" juga berasal dari bahasa Yunani "Strategia" yang artinya " the art of the general “ yaitu seninya seorang jendral/panglima. Dengan demikian istilah strategi ini sebenarnya berasal dari istilah kemiliteran yaitu usaha untuk mendapatkan posisi yang menguntungkan dengan tujuan mencapai kemenangan. Istilah ini kemudian berkembang daalam berbagai bidang kehidupan termasuk dalam dunia ekonomi, seperti strategi industri, strategi perencanaan, strategi pemasaran, dan dalam dunia pendidikan.

Pengertian kata strategi berkembang menjadi "skill in managing any affairs " yang artinya ketrampilan dalam mengelola/menangani suatu masalah. Bahkan kata strategi ini sudah menjadi bagian ilmu yaang berdiri sendiri yaitu "Strateies", science or art of strategy “ yang maksudnya ilmu atau seni strategi. Jika kata strategi ini dimaksudkan dalam dunia pendidikan secara makro dalam skala global, strategi merupakan kebijakan-kebijakan, yang mendasar dalam pengembangan pendidikan untuk tercapainya tujuan pendidikan secara lebih terarah, lebih efektif dan efisien. Jika dilihat secara mikro dalam strata operasional khususnya dalam proses belajar mengajar maka pengertiannya adalah langkahlangkah yang mendasar yang berperan besar suksesnya proses belajar mengajar. ${ }^{14}$

Para ahli pendidikan mengidentifikasi ada empat elemen yang perlu diperhatikan dalam cakupan strategi ini.

\footnotetext{
${ }^{13}$ Abd A'la, Pembahruan Pesantren(Yogyakarta: LkiS, 2006)

${ }^{14}$ Jamaluddin Darwis, Dinamika Pendidikan islam
} 
1. Identifikasi tujuan yang akan dicapai, yaitu apa yang menjadi tujuan dan seberapa nbanyak yang akan dicapai. Tujuan ini terkait dengan sikap hidup, pengetahuan, dan keterampilan yang dibutuhkan dan akan dapat dicapai melalui pendidikan.

2. Pertimbangan dan penentuan cara pendekatan yang dipakai untuk mencapai tujuan.

3. Pertimbangan dan penetapan langkah-langkah yang ditempuh sejak dimulainya proses pendidikan sampai pencapaian tujuan.

4. Pertimbangan dan penetapan tolak ukur untuk mengukur tingkat pencapaian tujuan pendidikan.

Dengan demikian empat unsur strategi dasar itu pelaksanaannya dalam pendidikan dengan memperhatikan pengertian pendidikan itu sendiri lebih dahulu. Secara umum pendidikan dapat diartikan proses pendewasaan dalam berbagai aspek kehudupan, baik dewasa dalam sikap hidupnya, cara berpikirnya maupun ketrampilannya dalam menjalani kehidupan. Proses pendewasaan ini di pihak peserta belajar dilaksanakan dengan proses belajar. Kegiatan belajar sebagai unsur utama dari pelaksanaan pendidikan secara diartikan sebagai proses perubahan tingkah laku baik sikap hidupnya (prilaku afektif), pengetahuannya (perilaku kognitif), maupun ketrampilannya (prilaku psikomotorik). Dengan demikian unsur pertama dalam strategi yang berkaitan dengan pengidentifikasian tujuan harus jelas cakupan spesifikasi sasarannya, kognisinya, afeksinya dan psikomotornya, dan klasifikasi pencapaiannya yaitu seberapa luas kognisinya, seberapa dalam afeksinya dan seberapa trampil/ mahir psikomotornya. Dengan demikian perolehan yang akan dicapai dalam pendidikan akan dapat diketahui (Observable) pencapaiannya dan sekaligus dapat diukur (Measurable) kualitasnya. Sebagai contoh dalam pendidikan formal, berkaitan dengan kurikulum Pendidikan Agama Islam ketika mengajarkan shalat, tujuannya adalah agar peserta didik mampu melaksanakan ibadah shalat. Perumusan tujuan ini akan mencakup pemahaman tentang tata cara shalat (kognitif), sikap kesadaran tentang kewajiban shalat (afektif), serta tampil dalam melafadzkan bacaan shalat dan gerakan shalat (motorik). 
Demikian juga pemikiran dan operasionalisasi manejemen pendidikan terpadu akan banyak ditentukan oleh tujuan dan arah keterpaduan, yang menyatakan bahwa arah pendidikan di pondok pesantren saat ini adalah dalam pembinaan IMTAQ, IPTEK dan skill fungsional atas dasar kebutuhan. Keterpaduan akan ditekankan dalam menata manajemen dan implementasinya yang untuk saat ini harus dimiliki oleh lembaga pendidikan pesantren dengan trategi dengan strategi pengembangan pendidikan yang telah dirumuskan.

Atas dasar beberapa pemikiran di atas, pembahasan kita berfokus pada masalah implementasi ide, konsep, kebijakan, atau inovasi dalam suatu tindakan praktis sehingga memberikan dampak, baik berupa perubahan pengetahuan, ketrampilan, maupun nilai, dan sikap.

\section{Pendidikan Sebagai Peningkatan Kualitas Hidup}

Pendidikan merupakan sistem dan cara meningkatkan kualitas hidup manusia dalam segala aspek kehidupan manusia. Dalam sejarah umat manusia, hampir tidak ada kelompok manusia yang tidak menggunakan pendidikan sebagai alat pembudayaan dan peningkatan kualitasnya, sekalipun masyarakat yang masih terbelakang (primitif). Pendidikan merupakan bagian terpenting dari kehidupan manusia yang sekaligus membedakan manusia dengan hewan. Oleh karena itu pendidikan sebagai usaha untuk melestarikan dan mengalihkan serta mentransformasikan nilai-nilai kebudayaan dalam segala aspek kehidupan guna mengangkat harkat dan martabat manusia. Oleh sebab itu, pendidikan merupakan kebutuhan penting bagi setiap manusia, negara, dan maupun pemerintah. Maka, pendidikan diharapkan elastis dan terus ditumbuhkembangkan secara sistematis oleh para pengambil kebijakan yang berwenang yang biasa diistilahkan dengan kebijakan pendidikan atau politik pendidikan. Dari kerangka ini, upaya pendidikan yang dilakukan suatua bangsa selalu memiliki hubungan yang signifikan. Sebab, pendidikan akan dihadapkan pada perubahan, baik perubahan zaman maupun perubahan masyarakat yang membutuhkan skill baru bagi generasi selanjutnya. Oleh karena itu, mau tidak mau pendidikan harus didesain mengikuti 
irama perubahan tersebut, kalau tidak, pendidikan akan ketinggalan. Tuntutan pembaruan atau modernisasi pendidikan menjadi keharusan dan modernisasi pendidikan pula yang akan mengikuti dan menempatkan pendidikan untuk tetap relevan dengan kebutuhan masyarakat, baik pada konsep kurikulum, proses, fungsi, tujuan, manajemen lembaga-lembaga, dan sumber daya pengelola pendidikan.

Kondisi pendidikan Islam di Indonesia, sebenarnya menghadapi nasib yang sama. Artinya jika ditilik secara mikro, pendidikan Islam menghadapi berbagai persoalan dan kesenjangan dari berbagai aspek yang sangat kompleks, yaitu berupa persoalan dikotomi pendidikan, kurikulum, tujuan, sumber daya, serta manajemen pendidikan Islam. Upaya perbaikan internalitas tersebut bulum dilakukan secara mendasar sehingga terkesan seadanya saja bahkan asal-asalan yang tidak memberikan alternatif yang solutif. Usaha modernisasi dan peningkaatan pendidikan Islam sering bersifat sepotong-sepotong (parsial) atau tidak komprehensif dan menyeluruh (holistik) serta sebagian besar sistem dan lembaga pendidikan Islam belum dikelola secara profesional.

Di Indonesia, kita kenal berbagai bentuk dan jenis lembaga pendidikan Islam, seperti pondok pesantren, madrasah, sekolah umum yang becirikan Islam, perguan tinggi Islam, dan jenis-jenis pendidikan Islam luar sekolah, Taman pendidikan Al-Qur'an (TPA), majelis taklim, dan sebagainya. ${ }^{15}$ Semua lembaga pendidikan Islam itu merupakan aset khazanah dan salah satu dari konfigurasi sistem pendidikan nasional Indonesia yang juga memberikan kontribusi terhadap penbentukan kepribadian generasi bangsa dan umat Islam secara khusus di Indonesia secara optimal. Namun, kenyataannya masih belum demikian. Pendidikan Islam di Indonesia tidak memiliki kesempatan yang luas untuk bersaing dalam membangun generasi bangsa dan umat Islam yang besar ini. Memang hal ini terasa janggal atau bahkan mungkin juga lucu. Sebab dalam suatu komunitas masyarakat muslim yang terbesar di dunia, lembaga pendidikan Islam seperti madrasah atau pesantren kurang mendapatkan kesempatan untuk

\footnotetext{
${ }^{15}$ Azyumardi Azra, Modernisasi Pendidikan Islam
} 
berkembang secara optimal atau bahkan tidak pernah dilirik. Mungkin ada benarnya juga, pepatah mengataakan "ayam mati kelaparan di lumbung padi” itu terjadi pada lembaga pendidikan Islam di Indonesia. Ini artinya, pada kenyataannya lembaga pendidikan Islam belum mendapat kesempatan yang luas dan seimbang dengan umatnya yang besar di bumi Indonesia ini.

Pendidikan dalam proses modernisasi mengalami perubahan fungsional antar sistem. Perubahan-perubahan tersebut pada tingkat konseptual dapat dirumuskan dengan menggunakan pendekatan sistem yang dalam hal ini bisa dilihat dari kajian-kajian modernisasi dengan menemukan variabelnya yang relevan terhadap perubahan pendidikan ke arah yang lebih baik dan sesuai dengan harapan masyarakat. Variabel-variabel di bawah ini dapat diterapkan dalam agenda modernisasi pendidikan Islam dalam konteks Indonesia keseluruhan.

1. Ideologi-normatif. Tujuan-tujuan ideologi tertentu ini dapat diekspresikan dalam norma-norma nasional (Pancasila, misalnya). Menuntut sistem pendidikan untuk memperluas dan memperkuat wawasan nasional peserta didik. Selain itu, bagi negara-negara yang relatif baru merdeka di mana integrasi nasional merupakan agenda pokok, orientasi ideologis-normatif ini sangat ditekankan dalam pendidikan. Dalam kerangka ini, pendidikan dipandang suatu instrumet terpenting bagi pembinaan nation building bahkan sangat boleh jadi orientasi "ideologis" lama-katakanlah Islam, lambat atau cepat tergeser oleh orientasi nasional baru tersebut. Atau setidaknya, terjadi semacam anomali atau bahkan krisis identitas ideologis.

2. Mobilisasi politik. Kebutuhan modernisasi menurut sistem pendidikan untuk memproduksi kepemimpinan modernitas yang dapat menjaga, memelihara, serta meningkatkan agenda pembangunan, tugas ini harus diemban oleh lembaga pendidikan tinggi, misalnya IAIN untuk menerapkan kurikulum yang lebih berorientasi pada modernisme dan modernitas.

3. Mobilisasi ekonomi. Tuntutan kerja yang sangat tinggi menuntut sistem pendidikan untuk mempersiapkan peserta didik menjadi Sumber Daya Manusia (SDM) yang unggul dan mampu mengisi berbagai lapangan kerja yang tercipta 
dalam proses pembangunan. Dalam hal ini lembaga pendidikan bukan hanya sebagai media transfer saja, melainkan juga harus dapat memberikan ketranpilan dan keahlian.

4. Mobilisasi sosial. Mobilisasi sosial dalam modernitas menuntut pendidikan untuk memberikan akses ke arah tersebut. Oleh karena itu pendidikan Islam tidak cukup lagi sekedar pemenuhan kewajiban menuntut ilmu belaka, tetapi harus juga memberikan modal. Dengan demikian, kemungkinan akses bagian dari peningkaatan sosial.

5. Mobilisasi kultural. Modernisasi yang menimbulkan perubahan-perubahan menuntut sistem pendidikan untuk mampu memelihara stabilitas dan mengembangkan warisan budaya dalam pembangunan. Dalam hal ini, pendidikan Islam khususnya pesantren yang dapat menjangkau tuntutantuntutan tersebut.

\section{Penutup}

Pesantren merupakan lembaga pendidikan khas Indonesia dan karena kekhasannya itu pula, pesantren dengan segala komponen, tradisi, kultur dan metode yang digunakannya serta keunikannya telah menarik perhatian banyak ahli dan pengkaji untuk melakukan kajian serta riset baik dari kalangan insider maupun outsider. Dan sebagai pendidikan khas Indonesia, eksistensi pesantren diakui banyak kalangan telah memberikan kontribusi yang saangat besar bagi peningkatan kualitas kehidupan umat manusia, walau demikian pesantren harus tetap membenai diri dari berbagai kekurangan dan kelemahan baik maanajemen, kurikulum, metode yang digunakan apalagi di era mordernisasi dan globalisasi ini. Banyak peran telah dimainkan oleh dunia pesantren; baik aspek sosial, politik, perekonomian, budaya, dan tentunya aspek keagamaan yang merupakan basis studinya. Sebagai agen perubahan masyrakat, sangatlah besar terutama bagi penyebaran dan pembauran Islam di tengah masyarakat. Dalam tataran eksistensial, pesantren telah terbukti mampu survival di tengah derasnya arus modernisasi dengan beragam tantangan dan dampak negatif yang ditimbulkannya. 
Dalam konteks ini pesantren telah terbukti mampu berperan sebgai benteng moralitas bangsa. Sisi lain yang tak kalah pentingnya adalah peran pesantren sebagai lembaga pendidikan mau dan mampu menampung semua kalangan masyarakat, khususnya kelas bawah masyarakat Indonesia. Oleh karena itu pesantren harus dipertahankan keberadaanya dengan memelihara dan mempertahankan nilai-nilai keaagamaan (salaf) dan mengambil yang baru yang lebih baik .

\section{Daftar Pustaka}

Azyumardi Azra, Modernisasi Pendidikan Islam (Ar-Ruzz Media, 2011)

Abd A'la, Pembaharuan Pesantren. (Yogyakarta: LkiS, 2006)

Departemen Agama RI. Pola Pembelajaran di Pesantren. (Jakarta, 2001)

Zamakhsyari Dhofier, Tradisi Pesantren: Studi Tentang Pandangan Hidup Kyai. (Jakarta: LP3ES, 1982)

Darwis Damaluddin, Dinamika Pendidikan Islam. RaSAIL, 2010

Rahim Husni, Arah Baru Pendidikan Islam di Indonesia. (Jakarta: Logos, 2001)

Sildu Galba,.1995. Pesantren sebagai Wadah komunikasi. Jakarta: PT. Rineka Cipta

SM, Ismail dan Abdul Mukti (Ed.). 2000. Pendidikan Islam: Demokratisasi dan Masyarakat Madani. Yogyakarta: Pustaka Pelajar 